\title{
Self Concept and Values of Male and Female Employees Working in Banking Sector
}

\author{
Rani Tripathi ${ }^{1}$, Dr. Jaiprakash N. Choube ${ }^{2}$
}

\section{ABSTRACT:}

The present study was conducted to compare the self concept and Values of male and female employees in banking sector. The sample for the present investigation consists 120 employees from Jalgaon City. In order to select the sample from the banking systematic random sampling technique was involved. From banking both male and female subjects were included in the sample. The researcher used two standardized psychological tests the self-concept scale by Dr. Raj Kumar Saraswat (1984) and Kamal Dwivedi and Shagufta Hafiz (1998) value scale to collect the data from the field. The investigator used different statistical analysis viz, mean, S.D and ttest to analyze the data. It was found male employees in comparison to female employee have been found high on self concept. The male and female employees on values have been not found significance difference on values scale.

Keywords: Self concept, values, Bank Employees.

Banking is the helping hand of the people. Banking has facilitated in increasing the very important sectors of the financial system. The segment has translated the expectations and objectives of millions of people into certainty. As financial mediators, banks stand between depositors who make available money and borrowers who required money. Given how much commerce and individual wealth rests on healthy banks, banking is one of the most to a great extent regulated businesses in the world. Values have been explained theoretically in a various concepts. Valuing a purpose in this way requires computations that are away from an individual's competences.

Self concept and Values imitate human personal decisions and attitudes, resolutions and relationships, vision. Self concept and Values are look upon as attractive, essential, and held in high admiration by a challenging society in which a person lives. Thus values give importance and superiority to individual character by engaging an essential place in his life. Our Self concept and values may differ from one society to the other. The variables Self concept and values need to be studied properly, both from the theoretical and practical point of view. The study can help the make their positive attitude towards Self concept and value to improve their performance in personal component of profession.

${ }^{1} \mathrm{Ph} . \mathrm{D}$. Scholar, North Maharashtra University, Jalgaon

${ }^{2}$ Professor, V.V.M's S. G. Patil College Sakri Dist-Dhule

(C) 2015 I R Tripathi, J Chobe; licensee IJIP. This is an Open Access Research distributed under the terms of the Creative Commons Attribution License (http://creativecommons.org/licenses/by/2.0), which permits unrestricted use, distribution, and reproduction in any Medium, provided the original work is properly cited. 


\section{REVIEWS OF LITERATURE}

As Cheney (1983) has proposed, the content of employee communication may facilitate the identification process, because it discloses the goals, values and achievements of the organization.

Bolus (1982) concluded that grades in English, mathematics and science were more highly correlated with matching areas of self-concept than with general self-concept.

Campbell and Jennifer D (1990) examined self-esteem and clarity of the self-concept, the association between evaluative and knowledge components of the self. Four studies tested the hypothesis that the self concepts of low self-esteem (LSE) people are characterized by less clarity or certainty than those of high-self-esteem (HSE) people.

Chattopadhay (1991) reviewed Values and beliefs, which are the building blocks of an organization's culture, consist of symbols, communications scripts, events, myths, and ways of doing things.

Epstein and Seymour (1973) studied self-concept revisited: or a theory of a theory. In the presented study, researchers attempted to integrate phenomenological theories of the self-concept into a broader framework compatible with an objective approach.

Kowalczyk \& Pawlish (2002) studied Organizational culture is a set of assumptions, beliefs, and values.

M.Y. Ganai, Maroof Maqbool (2013) studied the values of male and female veterinary science doctors of skuast-k. There is no significant difference between male and female veterinary doctors on aesthetic value but female have slightly higher mean than male veterinary science doctors.

Sengupta (2004) studied the leader's values and leadership style shape an organizational culture through the influence of daily practices, tasks, and behaviors.

\section{OBJECTIVES}

i. To study and compare the Self concept of male and female employees of banking.

ii. To study and compare the values of male and female employees of banking.

\section{HYPOTHESES}

i. There exists significant difference between male and female employees of banking on Self concept.

ii. There exists no significant difference between male and female employees of banking on Values.

\section{DELIMITATION OF THE STUDY}

- The geographical area of the study was delimited to the banking employees Jalgaon City.

- Sample for the study was delimited to clerical and administrative employees in the age range between 22 and 50 .

- The present study is delimited to self concept and Value only. 
- Only co operative bank were selected for the investigation

\section{SAMPLE:}

For this study, 120 employees (60 Male and 60 Female) in the age range of 22 to 50 years were randomly selected from the Jalgaon District of Maharashtra state.

$\begin{array}{llll}\text { VARIABLES: } & & & \\ \text { Independent variables: } & \text { Area } & \text { G Jalgaon city } & \\ & \text { Gender } \quad: \quad 1 . \text { Male } & \text { 2. Female } \\ \text { Dependent variables: } & \text { 1. Score of self concept scale } & \\ & \text { 2. Score of Values scale } & \end{array}$

TOOLS:

The following tools were used for collecting data for the study:

a) Self-Concept Questionnaire (SCQ): Dr. Raj Kumar Saraswat (1984) The questionnaire was standardized and the inventory have contains 48 items. This test contains 48 items with the responses are scored according to weight age of 5 to 1 (very much to never). It provides six separate dimensions of self-concept i.e. physical, social, temperamental, educational, moral, and intellectual self concept.

b) Value Scale : Kamal Dwivedi and Shagufta Hafiz (1998) For study of values scale constructed by Kamal Dwivedi and Shgufta Hafiz is utilized. This scale measures seven types of values i.e. Theoretical, Political, Economic, Social, Aesthetic, Religious and Moral Values.

\section{DATA COLLECTION:}

After the selection of psychological tests, the sample of bank employees was approached within the premises of respective bank. To ensure quick and complete return of questionnaire, they were properly given to the selected sample of male and female employees. The data collected was subjected to statistical processing and results were obtained.

\section{STATISTICAL ANALYSIS:}

For the purpose of the analysis, Descriptive statistics statistical techniques were used. Here researcher amylase total score of self concept and values. The level of significance was set at 0.01 and 0.05 levels. 
ANALYSIS AND INTERPRETATION

H01 "There exists significant difference between male and female employees of banking on Self concept".

Table-1: Showing Mean, Standard Deviations, and t-Value of the Male and Female Employee ( $\mathrm{N}=60$ in Each Group) for self concept.

\begin{tabular}{|c|c|c|c|c|c|}
\hline Group & N & Mean & S.D. & 't' Value & Level of Significance \\
\cline { 1 - 3 } Male & 60 & 211.33 & 16.898 & \multirow{2}{*}{3.257} & Significance.* \\
\cline { 1 - 4 } Female & 60 & 201.70 & 15.470 & & \\
\hline
\end{tabular}

* Significant at .05 Level.

Table no. 1 shows the descriptive statistics of the self concept. The Mean of Male Employees 211.33 and for Male Employees 201.70, whereas for Male Employees S.D. 16.898 and S.D. for Male Employees 15.470, obtained t-value is 3.257 which is found no significant at 0.05 level. Therefore, it can be concluded that the $\mathrm{H} 01$ "There exists significant difference between male and female employees of banking on Self concept." is selected.

H02 "There exists no significant difference between male and female employees of banking on Values".

Table-2: Showing Mean, Standard Deviations, and t-Value of the Male and Female Employee ( $\mathrm{N}=60$ in Each Group) for Values.

\begin{tabular}{|c|c|c|c|c|c|}
\hline Group & N & Mean & S.D. & 't' Value & Level of Significance \\
\hline Male & 60 & 208.10 & 13.260 & \multirow{2}{*}{1.517} & N. S.* \\
\hline Female & 60 & 204.23 & 14.620 & & \\
\hline
\end{tabular}

* Significant at .05 Level.

Table no. 2 shows the descriptive statistics of the values. The Mean of Male Employees 208.10 and for Male Employees 204.23, whereas for Male Employees S.D. 13.260 and S.D. for Male Employees 14.620, obtained t-value is 1.517 which is found no significant at 0.01 and 0.05 level. Therefore, it can be concluded that the $\mathrm{H} 01$ "There exists no significant difference between male and female employees of banking on Values." is selected.

\section{FINDINGS}

Major findings of the present study are as under:

- There exists no significant difference between male and female employees of banking on Self concept.

- There exists no significant difference between male and female employees of banking on Values. 


\section{CONCLUSIONS AND DISCUSSION}

From the above said findings we can conclude that the male employees are high on self concept as compared to female employees but results have not shown much difference on self concept among male and female employees. Male employees are higher on self concept in comparison to female. The finding is supported by Cooley (1902), Mead (1934) have long maintained that one's self-concept results from social inter action with significant others as one develops ideas concerning what others think of one. The performance development of any area of industry requires development in values and self concept among employees. Based on the end result and discussions, it could be concluded that employees self concept and values are help them to improved their performance. supported by Ginzel, Kramer, \& Sutton (1992) Value diversity implies differing reactions to the justice of manager's actions. This challenges managers, who strive to build consensus within their departments about appropriate behaviors and the need to reconcile conflicting positions. Banking sector employees are playing important role in clerical and interpersonal level communications. If they can know their self concept and values it will be helps to make the performance better in banking sector and social level.

\section{ACKNOWLEDGEMENT}

This research article is a part of my $\mathrm{Ph}$. D. research work I completed at Jalgaon city under guidance of Dr. Jaiprakash N. Choube. I am highly grateful to my supervisor Dr. Jaiprakash $N$. Choube, his motivation and support has been enormous for my research experience. I would like to extend my sincere thanks to Mrs. Naina Patkar and Mrs. Jyotsna Palekar for their suggestions and motivation to my study.

\section{REFERENCES}

- Bolus, R., \& Shavelson, R.J. (1982) Self- concept; the interplay of theory and methods. Journal of Educational Psychology, 74, 3- 17.

- Cooley C. H. (1902) Human nature and social order. New York: Charles Scribner's and Sons.

- Ginzel, L. E., Kramer, \& Sutton (1992). Organizational impression management as a reciprocal influence process: The neglected role of the organizational audience. InB. Staw \& L. L. Cummings (Eds.), Research in organizational behavior (Vol. 15, pp. 227-266). Greenwich, CT: JAI.

- Kamal Dwivedi and Shagufta Hafiz (1998) Value Scale: Manual for values scale.

- Mead, G. H.Mind (1930) self, and society. Chicago: University of Chicago Press.

- R. K. Saraswat (1992) Manual for self-concept questionnaire, National Psychological Corporation, Agra.

- Rani Tripathi (2014) A study the Personality and achievement Motivation of among High School Students of Jalgaon District. The International Journal of Indian Psychology | ISSN 2348-5396 Volume 2, Issue 1

\section{INTERNET SOURCES}

\begin{tabular}{l|l|l} 
www.icssr.org & www.indabook.org & www.ijip.in \\
www.ncert.nic.in & www.oppapers.com & www.worlib.org
\end{tabular}

